\title{
SERUM STATUS OF ENDOGENOUS ANTIOXIDANT MARKERS: BILIRUBIN, ALBUMINS, TOTAL PROTEINS AND CREATININE IN MYASTHENIA GRAVIS PATIENTS
}

\author{
Aleksandar Stojanov ${ }^{1}$, Gordana Djordjevići, ${ }^{1,2}$ Srdjan Ljubisavljević1,2, \\ Jelena Stojanov ${ }^{3}$
}

\begin{abstract}
There is a lot of evidence pertaining to the ethiopathogenetic importance of oxidative stress in a number of autoimmune diseases, including some immune-mediated neurological diseases such as multiple sclerosis. However, the role of oxidative stress and oxidative status in patients with myasthenia gravis is still an under-researched area.

The aim of our research was to compare serum total and direct bilirubin, albumin, total proteins and creatinine levels in myasthenia gravis (MG) patients with healthy controls, and patients with multiple sclerosis (MS).

The subjects were divided into three groups (92 MG patients, 68 healthy controls and 74 MS patients). All MG patients were newly diagnosed, classified with MGFA Clinical Classification, and divided into two groups regarding onset age (early $<50$ years, late $\geq 50$ years), sex (male, female), thymus pathology (present, absent).

Serum antioxidant status was significantly lower in MG and MS group compared to the healthy controls $(p<0.05)$. There was no significant difference in serum antioxidant status between patients with MG and those with MS. Regarding MGFA Classification we have not found any correlation with serum levels of measured parameters.

Our findings suggested that there was a potential role of oxidative process in MG pathology. Among the analyzed parameters, direct bilirubin showed significantly lower value in women, the elderly and in the group of MG patients with pathologically altered thymus gland. Acta Medica Medianae 2018;57(4):05-13.
\end{abstract}

Key words: myasthenia gravis, serum antioxidants, oxidative stress

${ }^{1}$ Clinic of Neurology, Clinical Center Niš, Serbia

${ }^{2}$ University in Niš, Faculty of Medicine, Niš, Serbia

3Special Psychiatric Hospital "Gornja Toponica", Niš, Serbia

Contact: Aleksandar Stojanov

32 Ozrenska St., 18000 Niš, Serbia

E-mail: astojanov1986@gmail.com

\section{Introduction}

Oxidative stress (OS) is a disorder which appears as the result of prooxidant and antioxidant balance disturbance. When the free radical production overrides antioxidant capacity there is damage to cellular metabolism and cell structures (proteins, lipids, nucleic acids), which consequently results in cell death by necrosis and apoptosis. Antioxidants are substances that delay or prevent the oxidation of a substrate, thereby removing the chain reaction that creates the reactive oxidative species (ROS) (1). The previous research in the field of autoimmune and inflammatory diseases, suggested an important role of oxidative stress in the etiopathogenesis of these diseases, e.g. multiple sclerosis (MS) $(2,3)$.

Chronic acquired myasthenia gravis (MG) is an antigen-specific autoimmune disease of postsynaptic neuromuscular membrane, which is characterized by the impairment of neuromuscular transmission, usually mediated by antibodies against the nicotinic acetylcholine receptor (4). Myasthenia gravis is etiopathogenically a well defined autoimmune disease, but correlation between MG and OS is still insufficiently explored area. Sporadic results suggested that excessive production of free radicals can cause the inactivation of nicotinic acetylcholine receptors and damage to the neuromuscular junction (5, $6)$. There is also evidence of oxidative stress in other neuromuscular disorders (7).

The results indicate a significant role of bilirubin, creatinine and albumin in the antioxidant protection system. There are studies that show pronounced antioxidant activity of bilirubin (8). Furthermore, this molecule plays an important immunomodulatory role (9). Albumin is a major antioxidant in plasma, which is mainly based on its role in the binding of different molecules (10), and values of total proteins are signi- 
ficantly lower in the plasma that has been treated with ROS sources (11). Creatinine is normally found as an energy depot in skeletal muscle, and has a role in the overall antioxidant status in serum and in reducing global oxidative stress (12).

\section{The aim}

The aim of our research was to evaluate serum levels of total and direct bilirubin, albumins, total proteins and creatinine as antioxidative status parameters in myasthenia gravis patients and to compare these values with those in healthy control group. Also, our objective was to liken values of these parameters in patients with another autoimmune neurological disease, such as multiple sclerosis, and finally, to perceive the obtained values of tested parameters in relation of different clinical and paraclinical patients characteristics (sex, age of onset, thymus pathology, disease classification).

\section{Material and methods}

The study included patients older than 18 years, suffering from acquired autoimmune myasthenia gravis, those hospitalized in the Clinic of Neurology, Clinical Center Niš, from January 2012 to December 2016, with a previous history of complaints for a period not longer than one year. The diagnosis of MG was based on the patients' history, physical examination, a prostigmine test, repetitive nerve stimulation test results, and the exclusion of other possible causes of symptoms, according to currently used criteria. We divided patients with MG into groups according to sex, age at the time of the disease onset ( $<50$ years, $\geq 50$ years) and the presence of pathologically altered thymic gland. Severity of the disorder was expressed according to the classification of the Myasthenia gravis foundation of America (MGFA Classification) at the time of serum sampling.

All subjects with previous history, clinical or laboratory findings which indicate renal or liver failure, diabetes mellitus, gout or some neurodegenerative disorder, were excluded. One control group consisted of healthy subjects, nonsmokers, with no evidence of the existence of autoimmune diseases or other diseases with proved pathogenic role of oxidative stress (e.g. diabetes mellitus, gout). The second control group consisted of newly diagnosed patients suffering from multiple sclerosis, in which disease diagnosis was made on the basis of the revised McDonald criteria of 2010, and at the time the study was performed disease was clinically presented as exacerbated.

Serum samples were taken in all subjects in the early morning, after 12 hours of fasting. Immediately after sampling and sample-labeling, they were sent to a laboratory for further testing. Serum total bilirubin (normal range 5.0-21.0 $\mu \mathrm{mol} / \mathrm{L}$ ), direct bilirubin (normal range $0-3.4 \mu \mathrm{mol} / \mathrm{L}$ ), albumin (normal range $35-53 \mathrm{~g} / \mathrm{L})$, total proteins $(62-81 \mathrm{~g} / \mathrm{L})$ and creatinine (normal range $53-115 \mu \mathrm{mol} / \mathrm{L}$ ) were measured using an AU680 Chemistry Analyzer (Beckman and Coulter, Switzerland). At the same time, aspartate transaminase (AST), alanine transaminase (ALT), blood urea nitrogen and blood sugar concentrations were also measured, to exclude patients with hepatic failure, renal failure and diabetes mellitus.

All data were statistically processed by IBM SPSS statistical software (version 21) for Windows operative system. Statistically significant were considered results with $p$ values less than 0.05 . Numerical data are presented as mean $\pm \mathrm{SD}$. All statistical calculations were performed using appropriated parametric or nonparametric tests after verification of values distribution in each group. The comparison between subgroups was performed using the KruskalWallis test.

\section{Results}

The serum samples were collected from 92 patients with MG, 68 healthy control individuals, and 72 patients with MS whose demographic characteristics (sex, age of onset) are displayed in Table 1. The patients with MG were divided in two groups, according to MSCT findings of the thymus gland (present or absent pathologic findings - thymoma and lymphoid thymus hyperplasia) as presented in Table 2. Based on the clinical assessment and data from the patients' history, all patients were classified according MGFA classification (Table 3).

The serum levels of total bilirubin, direct bilirubin, albumin, total proteins and creatinine were significantly lower in MG and MS group compared to the healthy control group ( $p<0.05)$. There was no significant difference of the investigated parameters concentrations between patients with MG and those with MS ( $p>0.05$ ) (Table 4; Graph 1, 2, 3).

Regarding the age of onset, we found significantly lower values of creatinine in the early onset group ( $p<0.05$ ), and lower values of direct bilirubin, albumines and total proteins in patients with the late onset of disease $(p<0.05)$. The serum levels of total bilirubin, albumin and total proteins showed no difference $(p>0.05)$ between the patients of different sexes. The values of creatinine and direct bilirubin were significantly lower in the female group $(p<0.05)$.

Regarding thymus pathology (absent / present), we have not found any correlation to the serum levels of the measured parameters ( $p>0.05)$, with an exception of direct bilirubin which levels were significantly lower in the group with present thymus pathology ( $p<0$.05). There was no statistical significance for measured parameters between groups of patients on the basis of MGFA Classification, ( $p>$ 0.05) (Tables 5 and 6). 
Table 1. The number of examinees based on sex and age at the beginning of the disease

\begin{tabular}{|c||c|c|c|c|c|}
\cline { 2 - 6 } \multicolumn{1}{c|}{} & $\mathrm{N}$ & Female & Male & $<50$ & $\geq 50$ \\
\hline \hline Myasthenia gravis & 92 & 56 & 36 & 50 & 42 \\
\hline Healthy control & 68 & 40 & 28 & 40 & 28 \\
\hline Multiple sclerosis & 74 & 43 & 31 & 54 & 20 \\
\hline
\end{tabular}

Table 2. The division of Myasthenia gravis patients in relation to the thymus pathology

\begin{tabular}{|c|c|c|c|c|}
\hline & & \\
\hline & & $\mathrm{N}$ & Female & Male \\
\hline \multirow{2}{*}{ Thymus pathology } & Absent & 24 & 14 & 10 \\
\hline & Present & 68 & 42 & 26 \\
\hline
\end{tabular}

Table 3. Number of patients according to the MGFA classification

\begin{tabular}{|c|c|c|}
\hline Class & Description & $\begin{array}{l}\text { Number of } \\
\text { patients }\end{array}$ \\
\hline Class I & $\begin{array}{c}\text { Any ocular muscle weakness. May have weakness of eye closure. } \\
\text { All othermuscle strength is normal. }\end{array}$ & 19 \\
\hline Class II & $\begin{array}{l}\text { Mild weakness affecting other than ocular muscles. } \\
\text { May also have ocular muscle weakness of any severity. }\end{array}$ & \\
\hline IIa & $\begin{array}{l}\text { Predominantly affecting limb, axial muscles, or both. } \\
\text { May also have lesser involvement of oropharyngeal muscles. }\end{array}$ & 22 \\
\hline IIb & $\begin{array}{l}\text { Predominantly affecting oropharyngeal, respiratory muscles, or both. } \\
\text { May alsohave lesser or equal involvement of limb, axial muscles, or both. }\end{array}$ & 14 \\
\hline Class III & $\begin{array}{l}\text { Moderate weakness affecting other than ocular muscles. } \\
\text { May also have ocular muscle weakness of any severity }\end{array}$ & \\
\hline IIIa & $\begin{array}{l}\text { Predominantly affecting limb, axial muscles, or both. } \\
\text { May also have lesser involvement of oropharyngeal muscles. }\end{array}$ & 15 \\
\hline IIIb & $\begin{array}{l}\text { Predominantly affecting oropharyngeal, respiratory muscles, or both. } \\
\text { May also have lesser or equal involvement of limb, axial muscles, or both. }\end{array}$ & 12 \\
\hline Class IV & $\begin{array}{l}\text { Severe weakness affecting other than ocular muscles. } \\
\text { May also have ocular muscle weakness of any severity. }\end{array}$ & \\
\hline IVa & $\begin{array}{l}\text { Predominantly affecting limb and/or axial muscles. } \\
\text { May also have lesser involvement of oropharyngeal muscles. }\end{array}$ & 4 \\
\hline IVb & $\begin{array}{l}\text { Predominantly affecting oropharyngeal, respiratory muscles, or both. } \\
\text { May also have lesser or equal involvement of limb, axial muscles, or both. }\end{array}$ & 4 \\
\hline Class V & $\begin{array}{l}\text { Defined by intubation, with or without mechanical ventilation, } \\
\text { except when used during routine postoperative management. }\end{array}$ & 2 \\
\hline
\end{tabular}

Table 4. Values of total and direct bilirubin, albumin, total proteins and creatinine in serum

\begin{tabular}{||c|c|c|c|c|c|}
\cline { 2 - 7 } \multicolumn{1}{c|}{} & $\begin{array}{c}\text { Total bilirubin } \\
(\mu \mathrm{mol} / \mathrm{L})\end{array}$ & $\begin{array}{c}\text { Direct bilirubin } \\
(\mu \mathrm{mol} / \mathrm{L})\end{array}$ & $\begin{array}{c}\text { Albumin } \\
(\mathrm{g} / \mathrm{L})\end{array}$ & $\begin{array}{c}\text { Total protein } \\
(\mathrm{g} / \mathrm{L})\end{array}$ & $\begin{array}{c}\text { Creatinine } \\
(\mu \mathrm{mol} / \mathrm{L})\end{array}$ \\
\hline $\mathrm{MG}$ & $11.09 \pm 3.72$ & $2.14 \pm 1.34$ & $61.56 \pm 8.13$ & $39.08 \pm 4.16$ & $78.50 \pm 15.11$ \\
\hline $\mathrm{HC}$ & $14.23 \pm 5.02$ & $2.63 \pm 1.30$ & $64.5 \pm 44.44$ & $40.50 \pm 3.02$ & $84.13 \pm 13.55$ \\
\hline $\mathrm{MS}$ & $10.49 \pm 2.75$ & $1.80 \pm 0.91$ & $62.56 \pm 5.71$ & $39.14 \pm 4.26$ & $76.68 \pm 8.82$ \\
\hline $\mathrm{P}^{1}(\mathrm{MG}$ vs. $\mathrm{HC})$ & $<0.001$ & 0.022 & 0.008 & 0.017 & 0.016 \\
\hline
\end{tabular}




\section{Total and direct bilirubin}

25

20

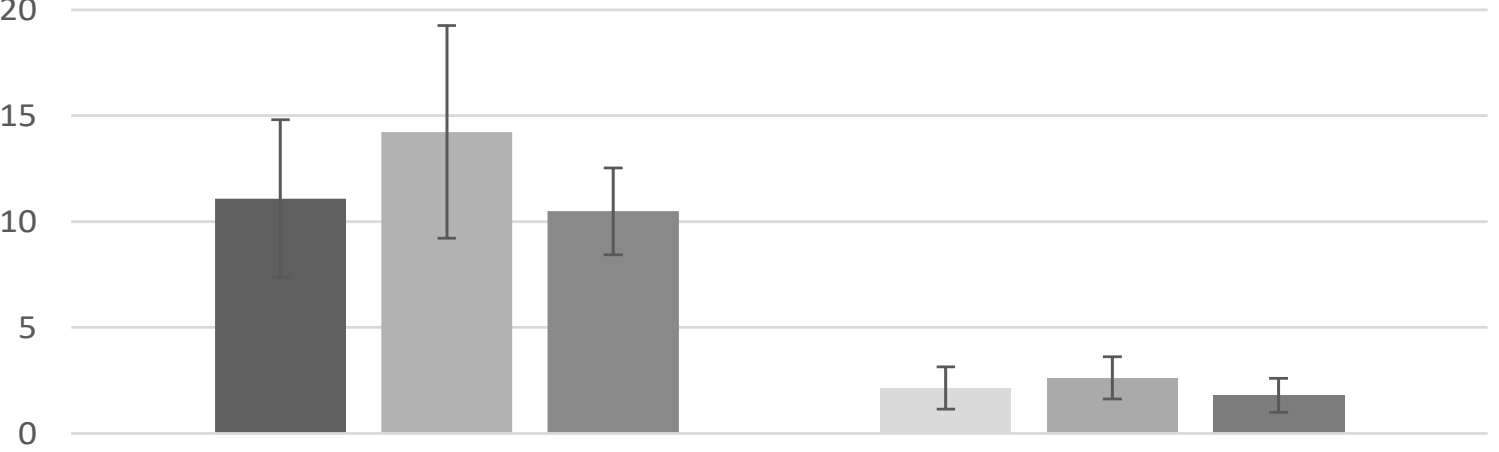

T bil

D bil

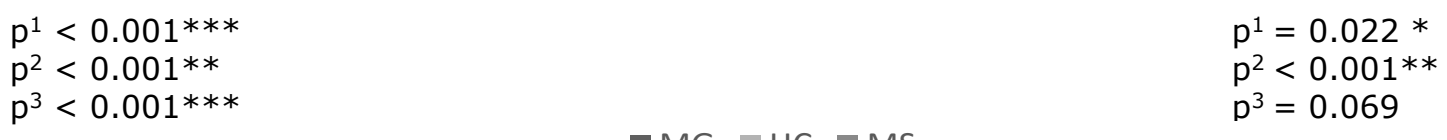

Grapf 1. Serum total and direct bilirubin levels ( $\mu \mathrm{mol} / \mathrm{L})$ in $M G$ and $M S$ patients and in healthy control (HC) group ( $\mathrm{p} 1=$ MG versus HC; $\mathrm{p} 2=\mathrm{HC}$ versus MS; $\mathrm{p} 3=$ MS versus MG; $\mathrm{p}<0.05^{*} ; \mathrm{p}<0.001^{* *}$ )

\section{Total proteins and albumins}

80

70

60

50

40

30

20

10

0
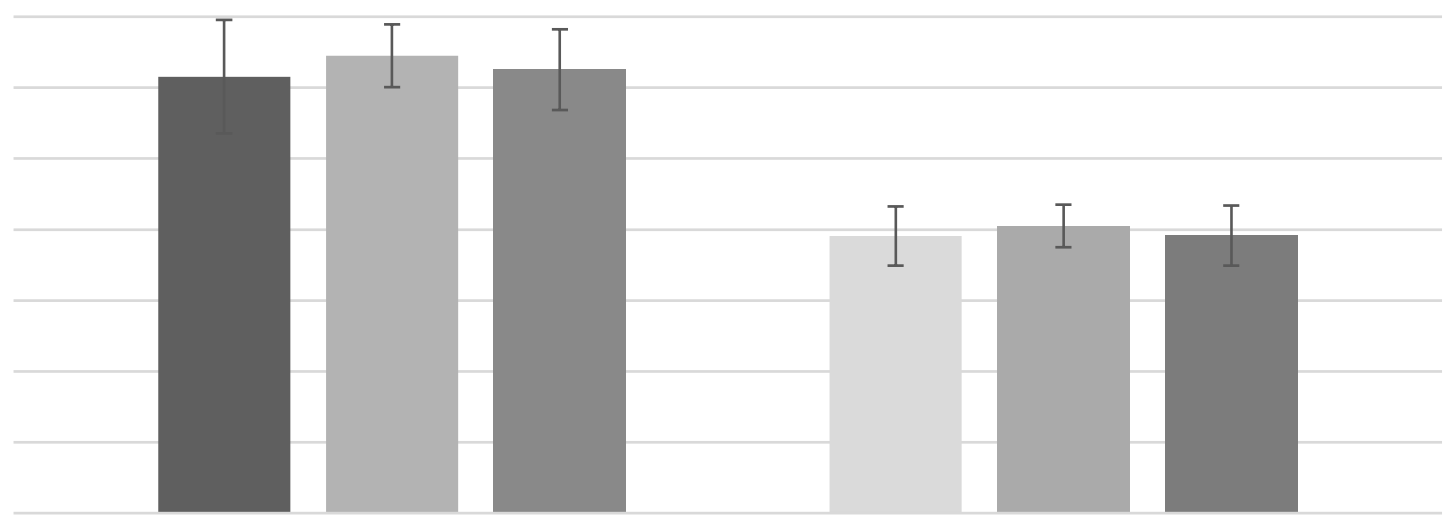

$\mathrm{p}^{1}=0.008^{*}$

T pro

$\mathrm{p}^{2}=0.026^{*}$

$\mathrm{p}^{3}=0.335$

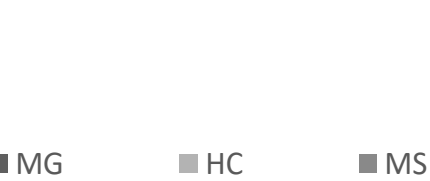

Alb

$$
\begin{aligned}
& \mathrm{p}^{1}=0.017 * \\
& \mathrm{p}^{2}=0.021 * \\
& \mathrm{p}^{3}=0.421
\end{aligned}
$$

\section{$\square \mathrm{MG} \quad \mathrm{HC} \quad \mathrm{MS}$}

Grapf 2. Serum albumin, and total protein levels $(\mathrm{g} / \mathrm{L})$ in $\mathrm{MG}$ and $\mathrm{MS}$ patients and in healthy control (HC) group ( $p 1=$ MG versus HC; $p 2=H C$ versus MS; $p 3=$ MS versus MG; $p<0.05^{*} ; p<0.001^{* *}$ ) 


\section{Creatinine}

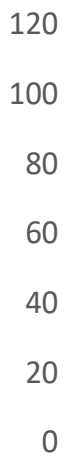

$\mathrm{p}^{1}=0.016^{*}$
$\mathrm{p}^{2}<0.001^{* *}$
$\mathrm{p}^{3}=0.361$

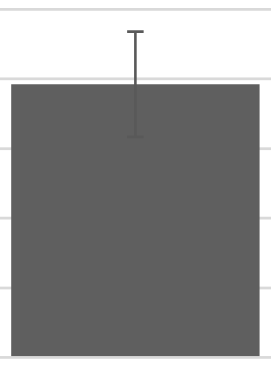

MG $\square \mathrm{HC} \square \mathrm{MS}$

Grapf 3. Serum creatinine levels ( $\mu \mathrm{mol} / \mathrm{L})$ in MG and MS patients and in healthy control $(\mathrm{HC})$ group ( $\mathrm{p} 1=$ MG versus HC; $\mathrm{p} 2=\mathrm{HC}$ versus MS; $\mathrm{p3}=$ MS versus MG; $\mathrm{p}<0.05^{*} ; \mathrm{p}<0.001^{* *}$ )

Table 5. Correlation between serum total and direct bilirubin levels with the age of onset, sex, MGFA clinical classification, and thymus pathology in patients with MG

\begin{tabular}{|c|c|c|c|c|c|c|}
\hline \multirow[b]{2}{*}{ Variables } & \multicolumn{3}{|c|}{ Total bilirubin $(\mu \mathrm{mol} / \mathrm{L})$} & \multicolumn{3}{|c|}{ Direct bilirubin $(\mu \mathrm{mol} / \mathrm{L})$} \\
\hline & Mean & SD & $P$ & Mean & SD & $P$ \\
\hline Age of onset & & & 0.119 & & & $0.024 *$ \\
\hline$<50(n=50)$ & 11.7 & 3.4 & & 2.5 & 1.9 & \\
\hline$\geq 50(n=42)$ & 10.7 & 4.3 & & 1.8 & 1.1 & \\
\hline Sex & & & 0.074 & & & $0.013 *$ \\
\hline male $(n=36)$ & 12.0 & 3.7 & & 2.8 & 2.1 & \\
\hline female $(n=56)$ & 10.8 & 4.0 & & 1.8 & 1.1 & \\
\hline MGFA & & & 0.275 & & & 0.058 \\
\hline$I(n=19)$ & 11.3 & 2.8 & & 2.2 & 1.1 & \\
\hline IIa $(n=22)$ & 11.4 & 5.6 & & 2.1 & 1.5 & \\
\hline IIb $(n=14)$ & 10.9 & 2.1 & & 2.0 & 0.9 & \\
\hline IIIa $(n=15)$ & 9.9 & 2.8 & & 1.7 & 1.1 & \\
\hline $\operatorname{IIIb}(n=12)$ & 10.5 & 2.5 & & 2.2 & 1.8 & \\
\hline IVa $(n=4)$ & 13.3 & 6.4 & & 3.0 & 2.2 & \\
\hline $\operatorname{IVb}(n=4)$ & 12.0 & 2.5 & & 2.4 & 1.1 & \\
\hline$V(n=2)$ & 16.3 & 5.4 & & 5.3 & 5.6 & \\
\hline Thymus pathology & & & 0.054 & & & $0.020 *$ \\
\hline present $(n=68)$ & 10.0 & 2.3 & & 1.65 & 0.7 & \\
\hline absent $(n=24)$ & 11.7 & 4.3 & & 2.43 & 1.8 & \\
\hline
\end{tabular}


Table 6. Correlation between serum creatinine, albumin and protein levels with the age of onset, sex, MGFA clinical classification, and thymus pathology in patients with MG

\begin{tabular}{|c|c|c|c|c|c|c|c|c|c|}
\hline \multirow[b]{2}{*}{ Variables } & \multicolumn{3}{|c|}{ Creatinine $(\mu \mathrm{mol} / \mathrm{L})$} & \multicolumn{3}{|c|}{ Proteins $(\mathrm{g} / \mathrm{L})$} & \multicolumn{3}{|c|}{ Albumin $(\mathrm{g} / \mathrm{L})$} \\
\hline & Mean & SD & $P$ & Mean & SD & $P$ & Mean & SD & $P$ \\
\hline Age of onset & & & $0.011 *$ & & & $0.013 *$ & & & $0.004 *$ \\
\hline$<50(\mathrm{n}=50)$ & 82.0 & 14.4 & & 59.6 & 7.8 & & 37.9 & 4.0 & \\
\hline$\geq 50(n=42)$ & 74.8 & 12.0 & & 63.8 & 8.0 & & 40.4 & 3.9 & \\
\hline Sex & & & $>0.001 *$ & & & 0.902 & & & 0.212 \\
\hline male $(n=36)$ & 85.3 & 13.4 & & 61.7 & 7.8 & & 38.4 & 4.0 & \\
\hline female $(n=56)$ & 74.5 & 12.4 & & 61.5 & 8.4 & & 39.5 & 4.2 & \\
\hline MGFA & & & 0.327 & & & 0.545 & & & 0.158 \\
\hline$I(n=19)$ & 78.3 & 13.3 & & 61.8 & 9.5 & & 39.1 & 3.8 & \\
\hline IIa $(\mathrm{n}=22)$ & 75.7 & 12.8 & & 61.8 & 7.6 & & 39.9 & 3.9 & \\
\hline $\operatorname{IIb}(n=14)$ & 81.0 & 10.9 & & 60.3 & 10.0 & & 37.8 & 4.2 & \\
\hline IIIa $(n=15)$ & 76.7 & 16.4 & & 64.0 & 6.3 & & 40.9 & 4.2 & \\
\hline $\operatorname{IIIb}(n=12)$ & 86.1 & 24.9 & & 59.7 & 5.9 & & 38.7 & 3.1 & \\
\hline IVa $(n=4)$ & 81.3 & 30.1 & & 55.8 & 7.0 & & 33.7 & 3.1 & \\
\hline $\operatorname{IVb}(n=4)$ & 81.2 & 22.0 & & 66.7 & 9.6 & & 39.8 & 6.2 & \\
\hline$V(n=2)$ & 99.8 & 14.0 & & 59.5 & 10.4 & & 37.7 & 6.0 & \\
\hline Thymus pathology & & & 0.398 & & & 0.082 & & & 0.102 \\
\hline present $(n=68)$ & 78.0 & 13.1 & & 60.7 & 8.1 & & 28.6 & & \\
\hline absent $(n=24)$ & 80.8 & 15.8 & & 64.0 & 7.8 & & 40.2 & & \\
\hline
\end{tabular}

\section{Discussion}

The link between MG and OS has not yet been established, but there is evidence of low antioxidative status in $M G$, including lower levels of creatinine, bilirubin, albumin, uric acid compared to healthy controls (13).

Lower serum bilirubin concentrations were noted in patients with MG compared to the healthy subjects, and significantly lower values in the females were observed, but no differences in respect to the modified Osserman classification (14) which corresponds to our results (Table 5). In our study, the value of direct bilirubin showed significantly lower values in women, late onset patients with MG and in patients with pathologically altered thymus.

The research conducted by Weng et al. showed that values of serum albumin were lower in patients with MG in correlation with values of healthy subjects and that it correlated with the degree of clinical presentation, so they could serve as a biomarker for the severity of the disease (15). Our research has not demonstrated a statistically significant difference in the value of the albumin related to the MGFA classification (Table 6 ). The ratio of serum albumin and clinical manifestation could be considered in the context of monitoring course of the disease and response rate for an individual patient. In here presented study, serum albumin and total proteins were significantly lower in late onset patients, which can indicate the significance of aging process for the mechanism of the total antioxidant defense decrease.

The contribution of creatinine in total antioxidant capacity is recorded (16). Our results showed lower values of creatinine in the patients suffering from MG and MS, indicating the reduced antioxidant capacity in these autoimmune neurological diseases (Table 4). Creatinine values were significantly lower in the female group, which was expected. In our study, only the creatinine values were lower in the early onset patients (for total bilirubin there was no statistical significance between the groups and for direct bilirubin, total proteins and albumins the values were lower in the late onset patients) (Table 5 and 6), which is consistent with the results of some previous studies on the impact of aging on the serum creatinine values (17).

In this study, the analysis of total bilirubin, albumin, total proteins and creatinine showed no statistically significant difference between the patients with and without changes in the thymus, which indicates that antioxidant protection is not correlated with the presence of pathology of the thymus (Table 
5 and 6). It should be emphasized that this was not the case with all tested biomarkers. Direct bilirubin levels were significantly lower in the group of patients with pathologically altered thymus. The question arises as to whether the altered bilirubin values are phenomenon associated with thymus pathology within the myasthenia gravis, or may have a primary pathogenetic significance in the development of thymus pathology. In this regard, further research is needed.

Yang et al. (13) found a statistically significant difference in the antioxidant status between patients classified by MGFA classification, while the research conducted by Fuhua et al. (18) has not recorded the same differences. Our results showed no significant statistical difference in any of the tested parameters compared to MGFA classification (Table 5 and 6). The lack of correlation could be explained by insufficient statistical pattern (the small number of patients in IVa, IVb and V group according to MGFA classification).

Oxidative stress has an impact on the activation of the complement system, which is the most important pathophysiological pathway that compromises neuromuscular transmission in patients with MG (19). Further studies on the connection between MG and oxidative stress can be guided in that direction. The recent studies have shown elevated values of oxidative and gluco-oxidative modifications in serum proteins of patients with MG (20). Further monitoring of oxidative stress parameters in these patients is necessary, especially in order to define appropriate biomarkers of the severity of the disease. As an advantage of our research, we emphasize the fact that to our knowledge, this is the first trial of creatinine, bilirubin, albumins and total proteins as antioxidant parameters (and the parameters of OS in general) in patients with MG, which has been done on a group of patients outside the Asian continent.

\section{Conclusion}

The results of our research showed significantly lower values of all investigated parameters in MG group related to the healthy control group, which could suggest a potential role of oxidative process in MG pathology. Among the analyzed parameters, direct bilirubin showed significantly lower value in women, in patients with the late onset of the disease, as well as in the group of MG patients with pathologically altered thymus gland. None of the investigated parameters correlated with severity of the clinical manifestation, so further research is needed in order to define a biomarker of oxidative stress as a potential marker of clinical progression in patients suffering from autoimmune acquired myasthenia gravis.
1. Halliwell B, Whiteman M. Measuring reactive species and oxidative damage in vivo and in cell culture: how should you do it and what do the results mean? $\mathrm{Br}]$ Pharmacol 2004; 142:231-55. [CrossRef] [PubMed]

2. Brambilla D, Mancuso C, Scuderi MR, Bosco P, Cantarella $G$, Lempereur $L$, et al. The role of antioxidant supplement in immune system, neoplastic, and neurodegenerative disorders: a point of view for an assessment of the risk/benefit profile. Nutr J 2008; 7:29-37. [CrossRef] [PubMed]

3. Gironi M, Borgiani B, Mariani E, Cursano C, Mendozzi L, Cavarretta R, et al. Oxidative stress is differentially present in multiple sclerosis courses, early evident and unrelated to treatment. J Immunol Res 2014; 2014: 961863 [CrossRef] [PubMed]
4. Gilhus NE, Vrschuuren JJ. Myasthenia gravis: subgroup classification and therapeutic strategies. Lancet Neurol 2015; 14(10):1023-36. [CrossRef] [PubMed]

5. Venkatesham A, Sharath BP, Vidya SJ, Krishna D. Effect of reactive oxygen species on cholinergic receptor function. Indian J Pharm 2005; 6:366-70.

6. Krishnaswamy A, Cooper E. Reactive oxygen species inactivate neuronal nicotinic acetylcholine receptors through a highly conserved cysteine near the intracellular mouth of the channel: implications for diseases that involve oxidative stress. Physiol 2012; 590 (1): 39-47. [CrossRef] [PubMed]

7. Stuerenburg $\mathrm{HJ}$. The roles of carnosine in aging of skeletal muscle and in neuromuscular diseases. Biochemistry (Mosc) 2000; 65:862-5. [PubMed] 
8. Jangi $S$, Otterbein $L$, Robson $S$. The molecular basis for the immunomodulatory activities of unconjugated bilirubin. Int J Biochem Cell Biol 2013; 45:2843-5. [CrossRef] [PubMed]

9. Peng F, Deng X, Yu Y, Chen X, Shen L, Zhong X, et al. Serum bilirubin concentrations and multiple sclerosis. J Clin Neurosci 2011; 18:1355-9. [CrossRef] [PubMed]

10. Roche M, Rondeau P, Singh NR, Tarnus E, Bourdon E. The antioxidant properties of serum albumin. FEBS Lett 2008; 582:1783-7. [CrossRef] [PubMed]

11. Tetik S, Kilic A, Aksoy H, Rizaner N, Ahmad S, Yardimci T. Oxidative stress causes plasma protein modification. Indian J Exp Biol 2015; 53(1):25-30. [PubMed]

12. Jansen EH, Beekhof PK, Cremers JW, Viezeliene D, Muzakova V, Skalicky J. Long-term stability of parameters of antioxidant status in human serum. Free Radic Res 2013; 47:535-40. [CrossRef] [PubMed]

13. Yang D, Su Z, Wu S, Bi Y, Li X, Li J, et al. Low antioxidant status of serum bilirubin, uric acid, albumin and creatinine in patients with myasthenia gravis. Int J Neurosci 2016; 126:1120-6. [CrossRef] [PubMed]

14. Zhou X, Sun ZW. Changes of serum bilirubin and uric acid in patients with myasthenia gravis. Zhonghua Yi Xue Za Zhi 2013; 93:1287-91. [PubMed]
15. Weng Y, Yang D, Qian M, Wei MM, Yin F, Li J, et al. Low serum albumin concentrations are associated with disease severity in patients with myasthenia gravis. Medicine 2016; 95(39):e5000. [CrossRef] [PubMed]

16. Nyasavajjala SM, Phillips BE, Lund JN, Williams JP. Creatinine and myoglobin are poor predictors of anaerobic threshold in colorectal cancer and health. J Cachex Sarcopenia Muscle 2015; 6:125-31. [CrossRef] [PubMed]

17. Tiao JY, Semmens JB, Masarei JR, Lawrence-Brown $M M$. The effect of age on serum creatinine levels in an aging population: relevance to vascular surgery. Cardiovasc Surg 2002; 10(5):445-51.

[CrossRef] [PubMed]

18. Fuhua $P$, Xuhui $D$, Zhiyang $Z$, Ying J, Yu Y, Feng T, et al. Antioxidant status of bilirubin and uric acid in patients with myasthenia gravis. Neuroimmuno-modulation 2012; 19:43-9. [CrossRef] [PubMed]

19. Collard CD, Lekowski R, Jordan JE, Agah A, Stahl GL. Complement activation following oxidative stress. Molecular Immunology 1999; 36:941-8. [CrossRef] [PubMed]

20. Adamczyk-Sowa M, Bieszczad-Bedrejczuk E, Galiniak S, Rozmiłowska I, Czyżewski D, Bartosz G, et al. Oxidative modifications of blood serum proteins in myasthenia gravis. Journal of Neuroimmunol 2017; 305: 145-53. [CrossRef] [PubMed] 


\title{
STATUS SERUMSKIH ENDOGENIH ANTIOKSIDATIVNIH MARKERA: BILIRUBINA, ALBUMINA, UKUPNIH PROTEINA I KREATININA KOD BOLESNIKA OBOLELIH OD MIJASTENIJE GRAVIS
}

\author{
Aleksandar Stojanov ${ }^{1}$, Gordana Đorđević ${ }^{1,2}$, Srđan Ljubisavljević1,2, \\ Jelena Stojanov ${ }^{3}$
}

${ }^{1}$ Klinika za neurologiju, Klinički centar Niš, Srbija

${ }^{2}$ Univerzitet u Nišu, Medicinski fakultet, Niš, Srbija

${ }^{3}$ Specijalna bolnica za psihijatrijske bolesti "Gornja Toponica", Niš, Srbija

Kontakt: Aleksandar Stojanov

Ozrenska 32, 18000 Niš, Srbija

E-mail: astojanov1986@gmail.com

Postoje brojni dokazi koji potvrđuju etiopatogenetski značaj oksidativnog stresa kod autoimunih bolesti, uključujući i neke imuno-posredovane neurološke bolesti, poput multiple skleroze. Međutim, uloga oksidativnog stresa i oksidativni status kod bolesnika sa mijastenijom gravis i dalje je nedovoljno istraženo područje.

Cilj našeg rada bio je uporediti nivoe antioksidativnih markera u serumu: ukupnog i direktnog bilirubina, albumina, ukupnih proteina i kreatinina, kod obolelih od mijastenije gravis (MG) sa rezultatima dobijenim u kontrolnoj grupi zdravih ispitanika i bolesnika obolelih od multiple skleroze (MS).

Ispitanici su podeljeni u tri grupe (92 bolesnika sa MG, 68 zdravih ispitanika i 74 bolesnika sa MS). Svi bolesnici sa MG su bili novodijagnostikovani, klasifikovani prema MGFA klasifikaciji i bili su podeljeni u grupe u odnosu na godine početka tegoba (rani početak < 50 godina, kasni početak $\geq 50$ godina), polu i patološki izmenjenom timusu (prisutno / odsutno).

Nivoi ispitivanih antioksidativnih markera u serumu bili su značajno niži u grupi bolesnika sa MG i MS u odnosu na zdrave kontrole $(p<0,05)$. Nije bilo statistički značajne razlike između MG i MS grupe. U odnosu na MGFA klasifikaciju, nije evidentirana korelacija sa serumskim nivoima ispitavnih parametara.

Naši rezultati ukazuju na potencijalnu ulogu oksidativnog stresa u patogenezi mijastenije gravis. Među ispitivanim parametrima kod bolesnika obolelih od mijastenije gravis vrednosti direktnog bilirubina su bile značajno niže kod žena, starijih bolesnika i bolesnika sa patološki izmenjenim timusom.

Acta Medica Medianae 2018;57(4):05-13.

Ključne reči: mijastenija gravis, serumski antioksidansi, oksidativni stres 